\title{
AN IT2FS MODEL FOR SHARIA CREDIT SCORING: ANALYSIS \& DESIGN
}

\section{Galih Kurniawan Sidik, Taufik Djatna, and Agus Buono}

Departemen Ilmu Komputer , Institut Pertanian Bogor, J1. Raya Darmaga Kampus IPB Darmaga Bogor

Email: pudesha@gmail.com

\begin{abstract}
Credit scoring system is a classic problem which is still interesting to study. There are many studies on credit scoring. But, most of them only discuss feasibility analysis. In fact, credit scoring system should accommodate all processes from feasibility analysis until the end of contract. This study is aimed to analyze and design scoring of default status and fines computation processes in Islamic bank. BPMN 2.0 was used to model their processes. Beside that, this study proposed new mechanisms and algorithms using Interval Type-2 Fuzzy Sets for maintaining Sharia rules and fairness guarantee. The results showed that the new methods offer more fair and comply to sharia than existing methods.
\end{abstract}

Keywords : information system, credit scoring, bank sharia, economy

\begin{abstract}
Abstrak
Sistem penilaian kredit merupakan masalah klasik yang masih menarik untuk dikaji. Terdapat banyak studi tentang penilaian kredit. Namun, kebanyakan hanya membahas analisis kelayakan. Bahkan, sistem penilaian kredit harus mengakomodasi semua proses dari analisis kelayakan sampai akhir kontrak. Penelitian ini bertujuan untuk menganalisis dan desain scoring status default dan proses perhitungan denda di bank syariah. BPMN 2.0 digunakan untuk memodelkan proses tersebut. Selain itu, penelitian ini mengusulkan mekanisme baru dan algoritma menggunakan Interval Type-2 Fuzzy Set untuk menjaga aturan Syariah dan jaminan keadilan. Hasil penelitian menunjukkan bahwa metode baru menawarkan keadilan lebih baik dan mematuhi syariah dibandingkan metode yang ada.
\end{abstract}

Kata Kunci: sistem informasi, credit scoring, bank syariah, ekonomi

\section{Introduction}

Credit scoring is a classic problem which is still interesting to study. Fisher's publication in 1936 is known as the first publication that introduce credit scoring system [8]. Recent years, there are many studies on credit scoring such as [4], [5], [7], [10], [16], [11], [8], [19], [20]. It is interesting to study because of the complexity in processes and data behavior that changes dynamically. The more interesting is most of the scholars only discuss credit scoring as feasibility analysis. Moreover, we can see from existing definitions that tend to equalize credit scoring as a credit feasibility analysis such as in [9], [20], [1].

In our opinion, credit scoring system should be able to accommodate all stages of the financing agreement until the expiration of the contract. In the process of Islamic finance, generally financing agreement process is initiated by financing feasibility analysis. This process is conducted to determine whether the customer's financing application is acceptable or not. If accepted, bank will negotiate margin. Usually, the result of financing feasibility analysis is considered as one of factors in margin determination. Then, bank will process contract signing and funds dropping. After that, bank will monitor the installment of debtors until the end of contract. This process is done by scoring process to determine default status for each debtor.

Usually, banks as well as Islamic banks determine score of default status is only considered by sum of late day installment (according to BI regulation no. 14/15/PBI/2012 tentang kualitas aset bank umum). Basic of this scoring schema is to classify credit risk for each customer. We believe that schema is not fair. As illustration, if we compare, customer A has installment amount 100,000 rupiahs and customer B has installment amount 2 million rupiahs, then both of them arrears 100 days in same, will both of them give same credit risk? Of course no. Thus, it should be design new more fair schema which is more useful in credit decision support systems.

Beside that, usually if customers arrears in installment, they will be charged a fines (penalty). The fines is obtained by multiplication between late day, certain percentage, and their credit amount 
(there are different treatment in different banks, many of them use installment amount as calculation, and the others use a remain debt). There are no rules regarding maximum amount of allowed fine. Thus, we believe that schema is not fair because in certain case will incriminate customers. As illustration, if fine percentage that determined by bank is $0.5 \%$. Customer $\mathrm{C}$ has 100 million of remain debt and 2 million of installment amount. Because of certain case, customer $\mathrm{C}$ arrears until 100 days, then he/she will pay his/her installment.Thus, he/she has to pay 7 million. Of course, this amount will incriminate him/her.

In conducting its operations, Islamic banks have adifferent principle from conventional banks. Besides aiming to maximize profit, Islamic banks have to comply sharia's rules and regulations based on Al-Quran and Hadith (Sharia compliance). According to principle in ushul fiqh, basic law of muamalah is allowed as long as no prohibition in verses and hadiths. Thus, in the implementation of the credit scoring system, Islamic banks may be possible to adopt the model that used in conventional banks that have been modified according to the guidance of Sharia based on relevant verses and hadiths.

If we observe rules or norms in Quran, hadiths, and other laws, many of them give the crisp rules such as rules about zakah mal calculation which is calculated by $2.5 \%$ of total assets, but the others just give normative rules that will cause multi-interpretation and uncertainty such as rules about fine (ta' zir in Islam). There are no rules from verses and hadiths that mention the crisp amount of fine. Even in guidance of MUI's national sharia board (DSN) no. 17 year 2000 that mention that fines calculation should be relied on the real lost value. Of course, the rules like that will cause multi-interpretation, uncertainty and different implementation in the practices.

Fuzzy logic is known as universal approximators. We know that in type-1 fuzzy sets, the membership function (MF) is a crisp value. According to [13], that will be a weakness if the problem has many uncertainties. Unlike type-1 fuzzy sets, type-2 fuzzysets (T2FS) use fuzzy value in MF calculation so that will accommodate the pro-blems that have many uncertainties [18]. It makes T2FS more promising to get better performance than type-1 fuzzy [13]. One of T2FS that have a lot of implementation in many areas is interval type-2 fuzzy sets (IT2FS). It is because IT2FS has less complexity than the other T2FS.

Thus, our research is aimed to analyze and design the sharia credit scoring model using IT2FS. In this research, we discuss about process of status default scoring (credit monitoring) and process of fines computation policy. Sharia financing schema which is discussed in this research is murabaha

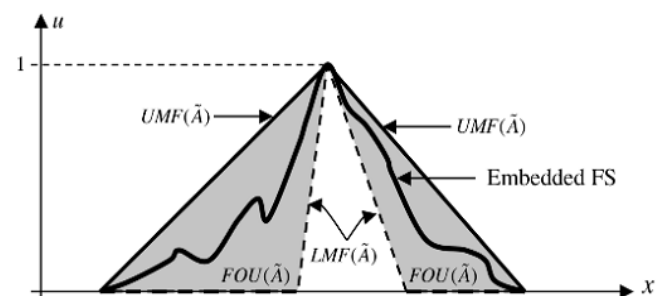

Figure 1. MF in IT2FS (cited from [13])

schema (see the definition in [2], [21]) because till now that schema still dominate the financing of Islamic bank in Indonesia [3].

\section{IT2FS}

T2FS model which is used in this research is IT2FS. IT2FS is one of type-2 fuzzy model that map the output to be interval value [13]. We use TSK method (Takagi, Sugeno, and Kang) for inferencing process. The selection of the model because it has a lower level of complexity than the other T2FS without reducing the result performance [13], [18], [12].

If the rule base on IT2FS consists of N rules, the general rules can be written as follows:

$R^{n}: I F x_{i}$ is $\tilde{A}_{1}^{n}$ and ... and $x_{I}$ is $\tilde{A}_{1}^{n}$ THEN $y$ is $Y^{n} ; n=$
$1,2,3, \ldots N$

On equation $1, \tilde{A}_{1}^{n}(i=1,2, \ldots I)$ id IT2FS whereas $Y^{n}=\left[y^{n}, \bar{y}^{n}\right]$ is interval value which is used as output.

We can see the MFs for IT2FS in Figure 1. MF IT2FS for $\tilde{A}$ can be written as $\operatorname{MF} \mu_{\tilde{A}}\left(x^{\prime}, u\right)$, for $x^{\prime} \in \mathrm{X}$ and $u \in J_{x^{\prime}} \subseteq[0,1]$, thus:

$$
\tilde{A}=\left\{\begin{array}{l}
\left(\left(x^{\prime}, u\right), \mu_{\tilde{A}}\left(x^{\prime}, u\right)=1\right) \mid \\
\forall x^{\prime} \in X, \forall u \in J_{x^{\prime}} \subseteq[0,1]
\end{array}\right\}
$$

where $x^{\prime}$ is called as primary variable and has domain $\mathrm{X}, u \in[0,1]$ is called as secondary variable and has domain $J_{x} \subseteq[0,1]$ at each $x^{\prime} \in X$; and $J_{x^{\prime}}$ is called as primary membership of $x^{\prime}$. Uncertainty level of $\tilde{A}$ can be characterized by union value of all primary membership $\left(J_{x^{\prime}}\right)$ which is called as footprint of uncertainty (FOU) of so that:

$$
\operatorname{FOU}(\tilde{A})=\bigcup_{\forall x^{\prime} \in X} J_{x}=\left\{\left(x^{\prime}, u\right): u \in J_{x^{\prime}} \subseteq[0,1]\right\}
$$

Upper membership function (UMF) and lower membership function (LMF) of $\tilde{A}$ are two MFs in type 1 fuzzy that bound the FOU. $U M F(\tilde{A})$ is an upper bound of $F O U(\tilde{A})$ and denoted as $\mu_{\bar{A}}\left(x^{\prime}\right)$, $\forall x^{\prime} \in X$. While $\operatorname{LMF}(\tilde{A})$ is lower bound of $F O U(\tilde{A})$ and denoted as $\mu_{A}\left(x^{\prime}\right), \forall x^{\prime} \in X$. So that:

$$
\operatorname{FOU}(\tilde{A})=\bigcup_{\forall x^{\prime} \in X}\left[\mu_{\underline{A}}\left(x^{\prime}\right), \mu_{\bar{A}}\left(x^{\prime}\right)\right]
$$


Generally, processes in IT2FS can be seen at Figure 2. In Figure 2, crisp input is fuzzified by MF rules in IT2FS. If we assume that input vector $\tilde{A}$ is $x^{\prime}=x_{1}^{\prime}, x_{2}^{\prime}, \ldots, x_{I}^{\prime}$, so that MF of $x_{i}^{\prime}$ at each $\tilde{A}_{i}^{n}$ can be written as follow:

$$
\left[\mu \underline{A}_{i}^{n}\left(x_{i}^{\prime}\right), \mu \bar{A}_{i}^{n}\left(x_{i}^{\prime}\right)\right] ; i=1,2,3, \ldots, I ; n=1,2,3, \ldots, N
$$

The results from fuzzification will become an input sets for IT2FS. Then, they will be inferenced by calculating the firing interval based on the rule set. Firing interval calculation can be obtained by using equation (6).

$$
\begin{array}{r}
F^{n}\left(x^{\prime}\right)= \\
\left.\mu \underline{A}_{1}^{n}\left(x_{1}^{\prime}\right) x \ldots x \mu \underline{A}_{I}^{n}\left(x_{I}^{\prime}\right), \mu \bar{A}_{1}^{n}\left(x_{1}^{\prime}\right) x \ldots x \mu \bar{A}_{I}^{n}\left(x_{I}^{\prime}\right)\right] \equiv \\
{\left[\underline{f}^{n}, \bar{f}^{n}\right]}
\end{array}
$$

Their output are still in IT2FS form, so that, the next process is type reduction from IT2FS to type- 1 fuzzy. There are many methods to do this, but our research use Karnik and Mendel algorithm which is known as KM algorithm (see equation (7) and (8)). Detail of KM algorithm can be seen at [13][18].

$$
y l=\frac{\sum_{i=1}^{L} \bar{f}^{n} \underline{y}^{n}+\sum_{i=L+1}^{N} \underline{f}^{n} \underline{y}^{n}}{\sum_{i=1}^{L} \bar{f}^{n}+\sum_{i=L+1}^{N} \underline{f}^{n}}
$$

TABLE 1

MF IT2FS IN SCORING FOR DEFAULT STATUS

\begin{tabular}{cc}
\hline Variable & Linguistic Value \\
\hline$\overline{\text { Late }}$ & Short, medium. long \\
$\underline{\text { Late }}$ & Short, medium, long \\
$\overline{\text { Amount }}$ & Short, medium, long \\
$\underline{\text { Amount }}$ & Short, medium, long \\
$\overline{\text { Default }}$ & Short, medium, long \\
Default & Short, medium, long \\
\hline
\end{tabular}

$$
y r=\frac{\sum_{i=1}^{R} \underline{f}^{n} \bar{y}^{n}+\sum_{i=R+1}^{N} \bar{f}^{n} \bar{y}^{n}}{\sum_{i=1}^{R} \underline{f}^{n}+\sum_{i=R+1}^{N} \bar{f}^{n}}
$$

Results from the type reduction will be an interval value $[y l, y r]$. Finally, the last stage is defuzzification process that convert the interval value to crisp value.This defuzzification is done by finding average value from the interval $[y l, y r]$ (see the equation (9)).

$$
y=\frac{y l+y r}{2}
$$

\section{Methodology}

\section{Scoring for Default Status}

According to our explanation in introduction part, scoring for default status is aimed to classify the

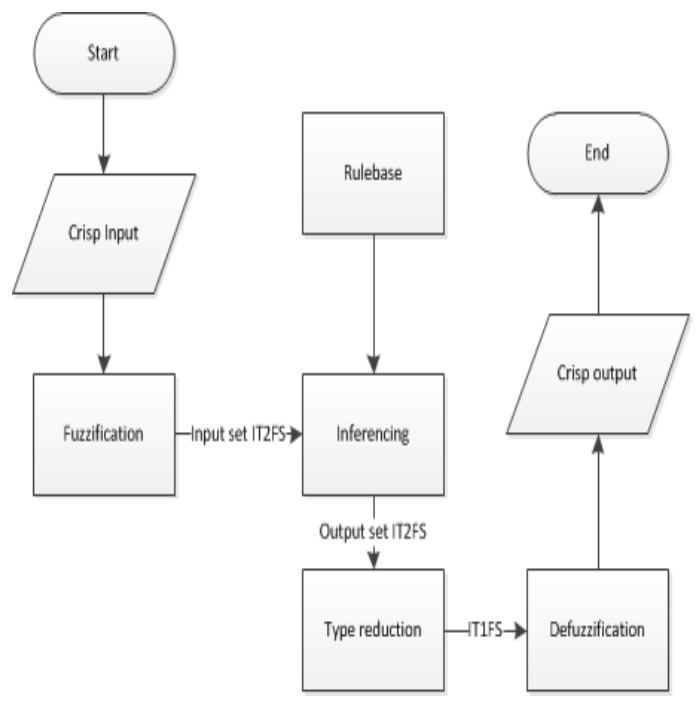

Figure 2. Flowchart of IT2FS

customers (debtor) based on their risk (credit). The existing process is only according to sum of late day. Therefore in this research, we use two parameters for scoring default status that are based on sum of late day and installment value which are expected more illustrate the credit risk for each customer rather than just based on sum of late day.

In this research, default status (default) is calculated by using IT2FS algorithm based on sum of late days (late) and installment value (amount) for each customer- $i$ (see equation (10)).

$$
\text { default }_{i}: \text { flate }_{i}, \text { amount }_{i}
$$

We design the default status value as interval value $[0,100]$. Lower credit risk is characterized by the closer value to zero (0). While the higher credit risk is characterized by the closer value to one hundred (100).

\section{IT2FS Model in Scoring for Default Status}

Fuzzification is done to convert crisp input to be fuzzy input. We assume that the model used in this process is trapezoid model. MF at each variable is converted by three ordinal scales, and according to IT2FS rules, MF for each variable has LMF and UMF; where LMF is characterized by underline, while UMF is characterized by over line (see table I).

In the MF calculation, late day MF in day unit (see equation (14), (15), (16), (17), (18), and (19)), installment MF in rupiah unit (see equation (20), (21), (22), (23), (24), and (26)), while default status MF in percentage unit (\%) (see Table 2). 


$$
\begin{aligned}
& \mu \overline{\text { lateShort }}\left(x^{\prime}\right)=\left\{\begin{array}{c}
0 x^{\prime}<14 \text { or } x^{\prime}>90 \\
\frac{90-x^{\prime}}{90-14} 14<x^{\prime} \leq 90 \\
1, x^{\prime}=14
\end{array}\right. \\
& \mu \underline{\text { lateShort }}\left(x^{\prime}\right)=\left\{\begin{array}{c}
0 x^{\prime}<14 \text { or } x^{\prime}>45 \\
\frac{45-x^{\prime}}{45-14} 14<x^{\prime} \leq 45 \\
1, x^{\prime}=14
\end{array}\right. \\
& \mu \overline{\text { lateMed }}\left(x^{\prime}\right)=\left\{\begin{array}{c}
0 x^{\prime}<60 \text { or } x^{\prime}>210 \\
\frac{x^{\prime}-60}{120-60} 60 \leq x^{\prime} \leq 210 \\
\frac{210-x^{\prime}}{210-150} 150 \leq x^{\prime} \leq 210 \\
1,120 \leq x^{\prime} \leq 150
\end{array}\right. \\
& \mu \underline{\text { lateMed }}\left(x^{\prime}\right)=\left\{\begin{array}{c}
0 x^{\prime}<90 \text { or } x^{\prime}>180 \\
\frac{x^{\prime}-90}{120-99} 90 \leq x^{\prime} \leq 120 \\
\frac{180-x^{\prime}}{180-150} 150 \leq x^{\prime} \leq 180 \\
1,120 \leq x^{\prime} \leq 150
\end{array}\right. \\
& \mu \overline{\text { lateLong }}\left(x^{\prime}\right)=\left\{\begin{array}{c}
0 x^{\prime}<180 \\
\frac{x^{\prime}-180}{270-180} 210 \leq x^{\prime} \leq 270 \\
1, \geq 270
\end{array}\right. \\
& \underline{\text { MlateLong }}\left(x^{\prime}\right)=\left\{\begin{array}{c}
0 x^{\prime}<210 \\
\frac{x^{\prime}-210}{270-210} 210 \leq x^{\prime} \leq 270 \\
1, \geq 270
\end{array}\right.
\end{aligned}
$$

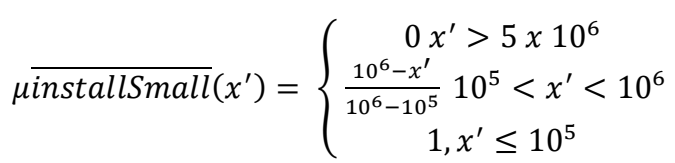

$$
\left\{\begin{array}{c}
\mu \underline{\text { installSmall }}\left(x^{\prime}\right)= \\
0 x^{\prime}>5 x 10^{5} \\
\frac{5 \times 10^{5}-x^{\prime}}{5 \times 10^{5}-10^{5}} 10^{5}<x^{\prime} \leq 5<10^{5} \\
1, x^{\prime} \leq 10^{5}
\end{array}\right.
$$$$
\text { } \overline{\text { installMed }}\left(x^{\prime}\right)=
$$$$
\left\{\begin{array}{l}
0 x^{\prime}<5 \times 10^{5} \text { or } x^{\prime}>5 \times 10^{6} \\
\frac{x^{\prime}-5 \times 10^{5}}{2 \times 10^{6}-5 \times 10^{5}} x^{\prime} \geq 5 \times 10^{5} \text { and } x^{\prime} \leq 2 \times 10^{6} \\
\frac{5 \times 10^{6}-x^{\prime}}{5 \times 10^{6}-3 \times 10^{6}} x^{\prime} \geq 3 \times 10^{6} \text { and } x^{\prime} \leq 5 \times 10^{6} \\
1, x^{\prime} \geq 2 \times 10^{6} \text { and } x^{\prime} \leq 3 \times 10^{6}
\end{array}\right.
$$

TABLE 2

MF DEFAULT STATUS

\begin{tabular}{ccc}
\hline Default & interval & $\overline{\text { interval }}$ \\
\hline Low & 0 & 40 \\
Middle & 30 & 70 \\
High & 60 & 100 \\
\hline
\end{tabular}

$$
\begin{aligned}
& \mu \underline{\text { installMed }}\left(x^{\prime}\right) \\
& =\left\{\begin{array}{c}
0 x^{\prime}<10^{6} \text { or } x^{\prime}>4 \times 10^{6} \\
\frac{x^{\prime}-10^{6}}{2 \times 10^{6}-10^{6}} 10^{6} \leq x^{\prime} \leq 2 \times 10^{6} x^{\prime} \geq 3 \times 10^{6} \\
\text { and } x^{\prime} \leq 4 \times 10^{6} \\
\frac{4 \times 10^{6}-x^{\prime}}{4 \times 10^{6}-3 \times 10^{6}} x^{\prime} \geq 2 \times 10^{6} \text { and } x^{\prime} \leq 4 \times 10^{6} \\
1, x^{\prime} \geq 2 \times 10^{6} \text { and } x^{\prime} \leq 3 \times 10^{6}
\end{array}\right.
\end{aligned}
$$

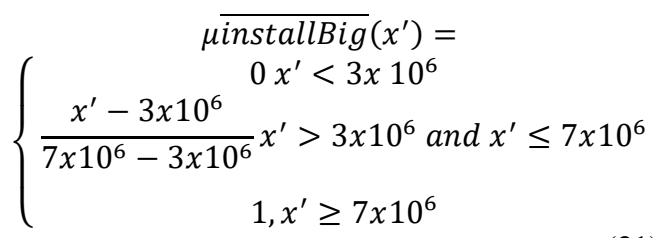

$$
\begin{gathered}
\frac{\mu \text { installBig }}{\left(x^{\prime}\right)=} \\
\left\{\begin{array}{c}
0 x^{\prime}<4 x 10^{6} \\
\frac{x^{\prime}-4 \times 10^{6}}{7 x 10^{6}-4 \times 10^{6}} x^{\prime}>4 \times 10^{6} \text { and } x^{\prime} \leq 7 \times 10^{6} \\
1, x^{\prime} \geq 7 \times 10^{6}
\end{array}\right.
\end{gathered}
$$

Based on discussion with the experts, we obtain nine (9) rules which is used in IT2FS model. The rules can be seen in Table 3 .

Then, the MFs dan the rules will be used in firing interval calculation as we see in equation (6), type reduction as in equation (7) and (8), and defuzzification process as in equation (9). Based on our models, the final output $\left(\right.$ default $\left._{i}=\mathrm{y}\right)$ will produce the interval value $[0,100]$ that will be used in fine calculation.

TABLE 3

\begin{tabular}{ccccccc}
\multicolumn{7}{c}{ RULE BASED MODEL IT2FS } \\
\hline No & & Late & \multicolumn{1}{c}{ Install } \\
\hline 1 & IF & short & AND & small & THEN & low \\
2 & IF & short & AND & middle & THEN & low \\
3 & IF & short & AND & big & THEN & middle \\
4 & IF & middle & AND & small & THEN & low \\
5 & IF & middle & AND & middle & THEN & middle \\
6 & IF & middle & AND & big & THEN & middle \\
7 & IF & long & AND & small & THEN & middle \\
8 & IF & long & AND & middle & THEN & high \\
9 & IF & long & AND & big & THEN & high \\
\hline
\end{tabular}

\section{Fines Computation}

According to Zuhaili [21], based on verses and hadiths, imposition of penalties (fines) on the late payment of the debt will be same with riba (usury) which is forbidden in Islam. But, based on his study, the imposition will be allowed if the debt is based on purchase contract. Murabaha financing is one of financing contract which is based on pur- 


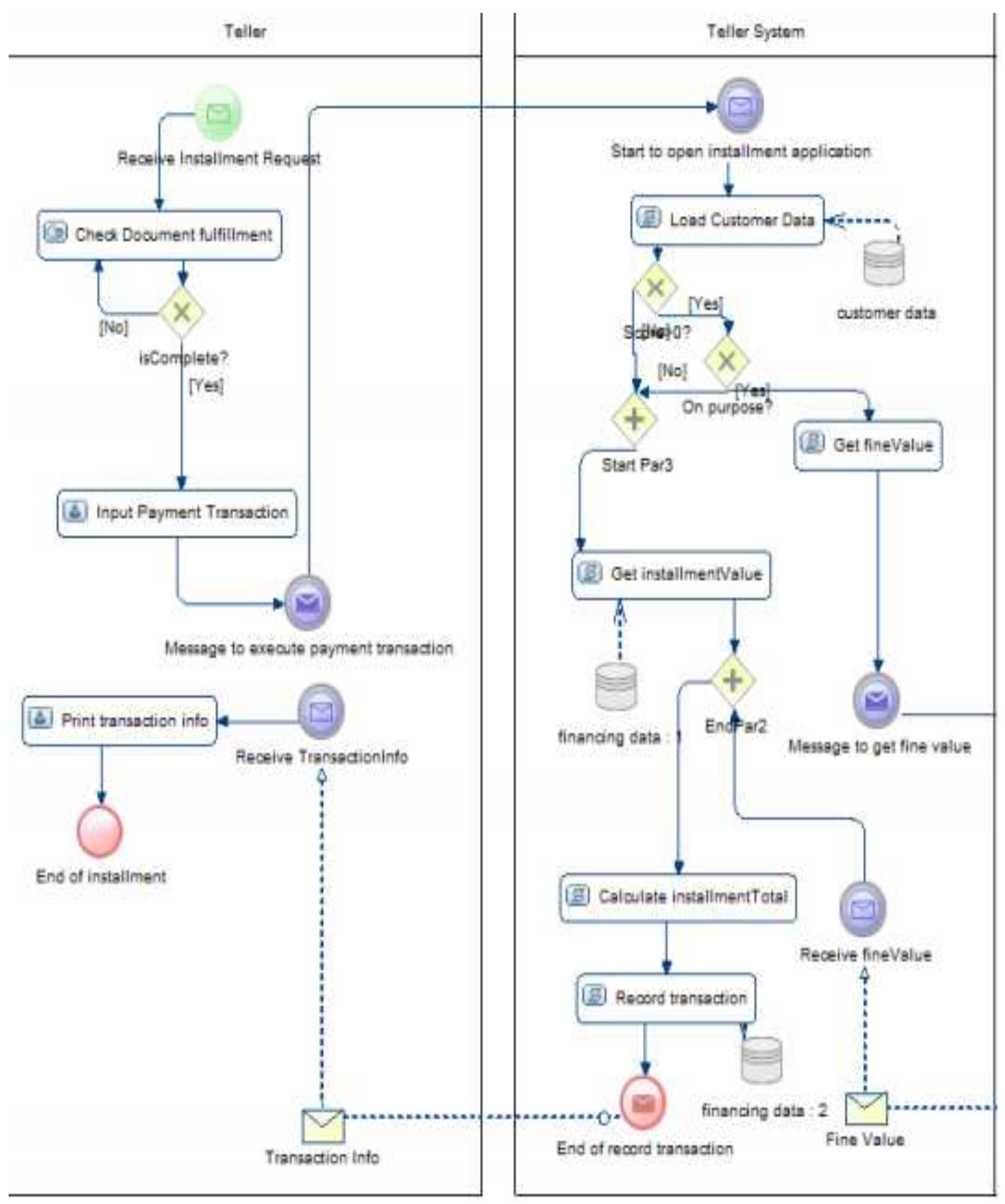

Figure 3. Business process model part 1

chase contract[2], [21]. This is in line with the guidance (fatwa) of DSN MUI no. 17 of 2000 which allows the imposition of fines to customers in order to make customers more disciplined. At the other provisions, generally the imposition of fines is only allowed for customers

who are able and deliberately delaying payment. But, unlike other financing contract, in murabaha contract we can assume that the customers are able to pay, so that if the customer delay the payment, it is considered as negligent and allowed to be fined.
Under the fatwa, the fine value should be based on the real lost value that may arise when the customer is arrears. However, on the other hand, the imposed fines value is solely to make customers more disciplined and may not be used for the benefit of the institutions.

Based on interview with some experts (DSN committee, BI, lecturer in muamalah, and some sharia bankers), there are two opinions regarding the determination of the real lost value. The first opinion, the banks have to actually calculate the re- 


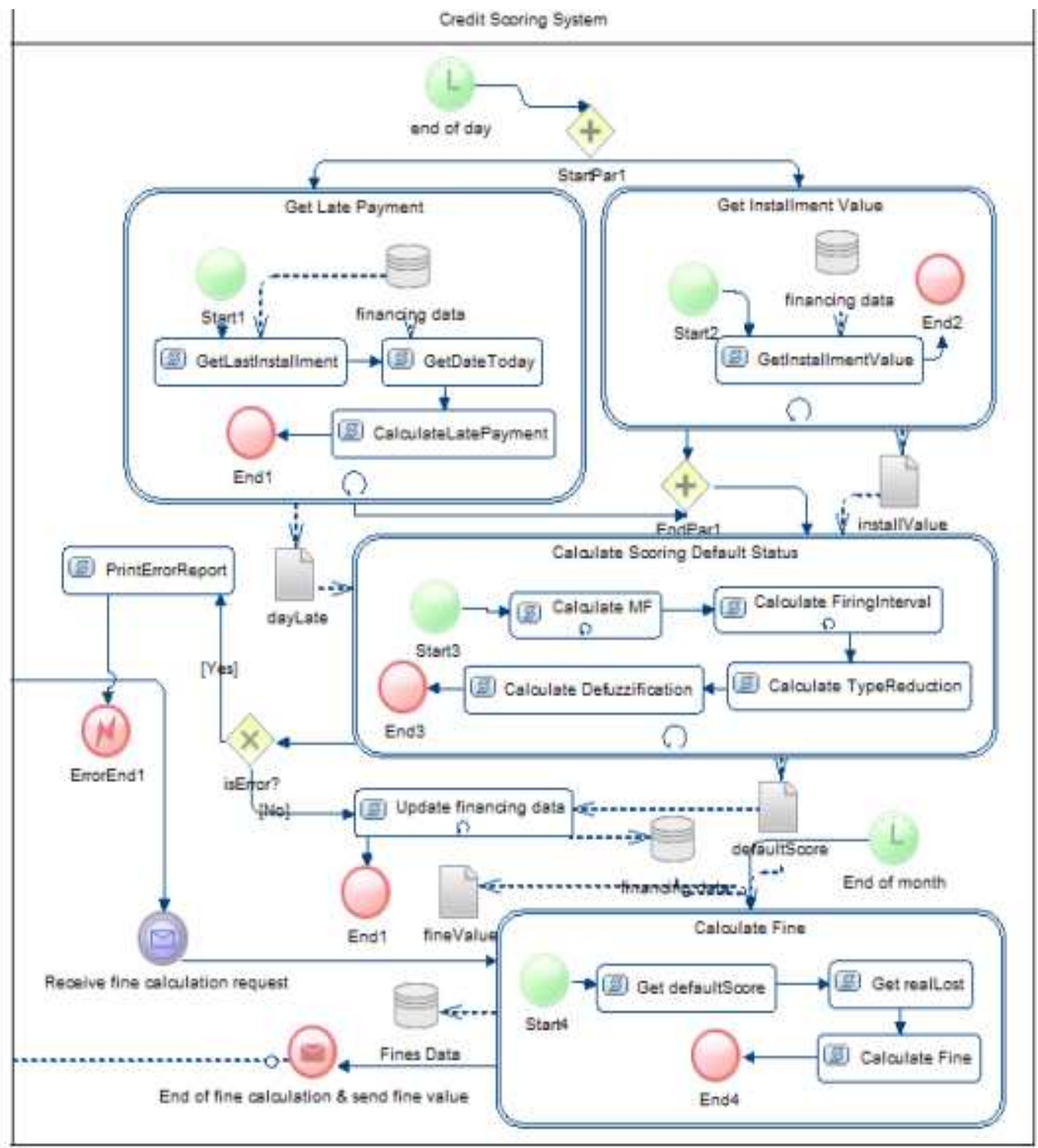

Figure 4. Business process model part 2

al lost value based on real conditions when the customers are arrears. While the second opinion, banks are allowed to calculate the estimated real lost value that may arise on the basis of relevant data and information. Furthermore, the data and information that would be relevant for the calculation of real lost is the value of bad debt expense or allowance for bad debt expense that have been periodically conducted by bank.

As our explanation before, we use interval value of default d $_{i}[0,100]$ as a percentage $(\%)$ of real lost. We hope that treatment can accommodate two opinions about real lost above. Thus, we establish two scenarios for fines computation.

\section{Scenario 1}

We will not discuss about the lost computation in real condition. We assume the real lost as $r$ rupiahs. The fines value (fines) is obtained by multiplication between $\mathrm{r}$ and result of IT2FS (default $_{i}$ ) (see equation (23)).

$$
\text { fines }_{i}=r * \text { default }_{i} / 100
$$

\section{Scenario 2}

Bad debt expense is the estimated value of collectable financing debt for all customers. Thus, if we assume bad debt expense as $b d$ rupiahs, then the fines value is obtained by multiplication between $b d$, result of IT2FS (default ${ }_{i}$ ), and the weighted ave- 


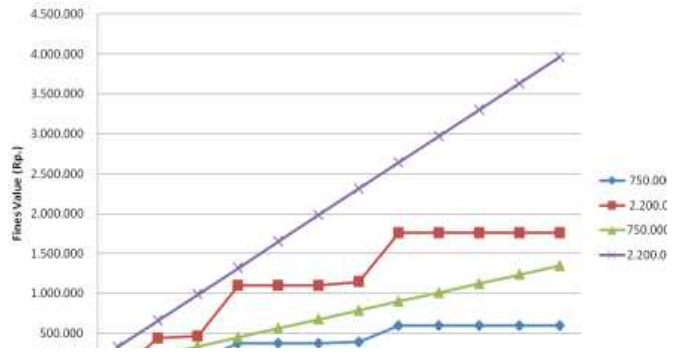

Figure 5. Result of scenario 1

rage of installment for each customer to total installment $\left(w_{i}\right)$ (see equation (24)).

$$
\text { fines }_{i}=b d * \text { default }_{i} * w_{i}
$$

If there are $N$ customers, then $w_{i}$ can be obtained by using weighted average as follows:

$$
w_{i}=\frac{\text { install }_{i}}{\sum_{i=1}^{N} \text { install }_{i}}
$$

\section{Business Process Model}

Monitoring process is conducted after financing approval and financing dropping process. This process is conducted during the financing agreement until the end of the contract. In this study, the monitoring is done by scoring the default status ( $d e$ ault). This score is obtained by using an IT2FS algorithm based on two variables (sum of late day (late) and installment amount (install)) for each customer (see equation 10). If there are arrears customers, then it will be imposed certain fines by calculation based on default values (see subsections 3.2, sub subsection 3.2.1 and 3.2.2).

We build the business process model using BPMN 2.0 (Business Process Modeling and Notation 2.0 version). According to [15], the validity of the model can be characterized based on three criteria: the complexity of each process, risk handling and planning, and communication among stakeholders.

Based on our analysis, we build a business process model for scoring default status and fines computations (see Figure 3 and 4). In general, we divide the processes into two major parts, installment process and the processes that occur in the credit scoring. Installment process is modeled as installment transaction process in general (see Figure 3). But, we can see the difference in terms of the imposition of fines. in Figure 3, we can see that the fines will be imposed if only if the customer can not prove that the delay that has occurred done inadver-tently. In other words, we can say that the fines will be imposed if only if the customer arrears on pur-pose.

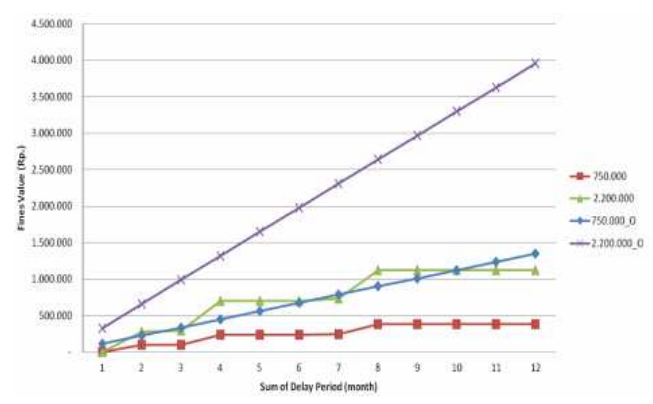

Figure 6. Result of scenario 2

On Figure 4, scoring process of default status is conducted every the end of day. The process is initiated by collecting sum of late days and the installment value. The next process is mapping them to be score of default status using an IT2FS algorithm. These processes are carried out for each customer. The score of default status will become the basis of the fines calculation. Then, these values will be updated into database. Hence, in the fines calculation, the system will just read these scores from database.

\section{Results and Analysis}

We conduct the trial on 2 customers that differ in installments amount (the customer whose installment value 750 thousand rupiahs and 2.2 million rupiahs). Both of customers data is hypothetical data which is created by following the rules in our transaction for each customer is fixed, so that we believe the trial periods which is only 12 months, will represent all of different characteristics of financing period, whether $1,3,5$ or even 20 years. In first scenario, we assume the maximum real lost value is equal with the installment value, while in second scenario, we assume the bad debt expense is $30 \%$ of installment total. Beside that, we compare our result with the conventional method by assuming that the fines percentage is $0.5 \%$ per late day. The result of first scenario can be seen in Figure 5, while the second scenario in Figure 6.model. We conduct the trial for 12 months of peri- ods. We assume the date value of last installment

In Figure 5 and Figure 6, Both of instance 750.000 and 2.200.000 are the result of our proposed method for customer whose installment value 750 thousand rupiahs and 2.2 million rupiahs, while the instance of 750.000_O and 2.200.000_O are the result of conventional method. We can see from the results in Figure 5 and.

Figure 6, in conventional method, the fines value will always be linear according to the number of late days without any maximum limit. While in proposed method, for each scenario, we consider the real lost values as an upper bound (maximum value) of imposed fines. This treatment is used to 
limit the fines such that the imposed fines will not incriminate the customers as well as in sharia rules. The scoring of default status value $[0,100]$ is used as a percentage (\%) of real lost value. The different between scenario 1 and scenario 2 lies in real lost calculation (see sub subbab 3.3.1 and 3.3.2). In scenario 1, upper bound of fines is a real lost value (real lost value $\leq$ installment value), so that the result of the fines calculation of the customer with high installment value (belong to MF $\overline{b i g}$ ) and high late days value (belong to MF $\overline{l o n g}$ ), maximum is equivalent or less than installment value. While in scenario 2, upper bound of real lost value will be adjusted by the result calculation of weighted average of each customer. So that, maximum imposed fines will be affected by the outcome of default score and weighted average calculation for each customer.

If the calculation process of real lost value in scenario 1 could be obtained on robust, we consider that scenario 1 will be more fair than scenario 2 . But, in fact, the calculation process of real lost value in scenario 1 will be more difficult and need more time and additional cost. Whereas in scenario 2 , the real lost value is obtained from bad debt expanse value which is commonly done by the bank periodically. Therefore, based on the test result and these considerations, we claim that scenario 2 is promising in its application.

\section{Conclusion}

In Islamic bank, sharia compliant is a must so that we model the credit scoring processes by considering the sharia rules. We use BPMN 2.0 as modeling notation their processes. We discuss two main processes, scoring the default status and fines calculation. We use IT2FS model in scoring the default status. This scoring process will result the interval value $[0,100]$ which will be used by fines calculation process as a percentage of real lost value. There are two experts opinions about real lost, consequently we propose two scenarios. Based on the results analysis, we claim that two proposed scenarios are more fair than the conventional method. Furthermore, we believe that scenario 2 is more promising in its application than scenario 1. Based on our business process model, the fines will be imposed if and only if the the customer can not prove that the delay was due to inadvertence.

\section{References}

[1] H.A. Abdou and J. Pointon, "Credit scoring, statistical techniques and evaluation criteria: A Review of the Literature," Intell. Syst. in Accounting, Finance, and Management 18, p. 59-88 (2011) doi: 10.1002/isaf.325
[2] M.S. Antonio, Bank syariah: dari teori ke praktek (Sharia bank: from theory to practice), Gema Insani Press (ID), 2001

[3] Bank Indonesia, Statistic of Sharia Bank in Indonesia, May 2012 (ID)

[4] Cadeno et al., "Artificial metaplasticity neural network applied to credit scoring," Int. J. Neural Syst., Vol 21, No 4 (2011) hal 1-7. doi: 10.1142/S0129065711002857

[5] A. Ghodselahi, "A hybrid support vector machine ensemble model for credit scoring," Int. J. Comp. Application vol. 17 No 5 March 2011

[6] A.Z. Hamadani et al., "An integrated geneticbased model of naive bayes networks for credit scoring," Int. J. Artificial Intell. \& Application (IJAIA) Vol. 4, No. 1, January 2013, doi:10.5121/ijaia.2013.4107

[7] C.L. Huang et al., "Credit scoring with a data mining approach based on support vector machine," Expert syst. with applications (2006) doi: 10.1016/j.eswa.2006.07.007

[8] H. Lu et al., "Credit scoring model hybridizing artificial intelligence with logistic regression," J. Networks, Vol. 8, No. 1, January 2013, doi: 10.4304/jnw.8.1.253-261

[9] N. Jentzsch, Financial privacy: an international comparison of credit reporting systems (contributions to economics). Springer, 2007

[10] A. Keramati and N. Yousefi, "A proposed classification of data mining techniques in credit scoring," Proc. 2011 Int. Conf. on Industrial Engineering and Operations Management Kuala Lumpur, Malaysia, January 22-24, 2011

[11] K. Leung et al., "Consumer credit scoring using an artificial immune system algorithm, " IEEE Congr. on Evolutionary Comp., 2007

[12] F. Liu and J.M. Mendel, "Encoding words into interval type-2 fuzzy sets using an interval approach," IEEE Trans. on Fuzzy Systems, Vol. 16, No. 6, December 2008, doi: 10.1109/TFUZZ.2008.2005002

[13] J.M. Mendel et al., "Interval type-2 fuzzy logic systems made simple," IEEE Trans. on Fuzzy Systems, Vol. 14, No. 6, December 2006, doi: 10.1109/TFUZZ.2006.879986

[14] R. G. Sargent, "Verification and validation of simulation models," Proceedings of the 2007 Winter Simulation Conference 1-4244-13060/07/\$25.00 @2007 IEEE pp. 124-137

[15] Shapiro R, White SA, Palmer N, Muehlen Mz, Allweyer T, Gagne D. 2011. BPMN 2.0 Handbook. Published in association with the Workflow Management Coalition (WfMC), Lighthouse Point, FL, USA: Future Strategies Inc 
[16] C.F. Tsai and J.W. Wu, "Using neural network ensembles for bankruptcy prediction and credit scoring," Expert syst. With applications, vol. 34. pp. 2639-2649, 2008

[17] Undang-Undang Republik Indonesia No. 21 tahun 2008 (ID)

[18] D. Wu and J.M. Mendel, "A comparative study of ranking methods, similarity measures and uncertainty measures for interval type-2 fuzzy sets," Information Sciences 179 (2009) 1169-1192, Elsevier Inc., doi: 10.1016/j.ins.2008.12.010
[19] W.W. Wu, "Improving classification accuracy and causal knowledge for better credit decisions," Int. J. Neural Syst., Vol 21, No 4 (2011) pp. 297-309. DOI: $10.1142 / \mathrm{S} 0129065711002845$

[20] L. Yu et al., Bio-inspired credit risk analysis: computational intelligence with support vector machines, Springer, 2008

[21] W. Zuhaili, Fiqhul Islam waadillatuhu. Indonesian version vol.5, translated by Abdul Hayyie al-Kattani. Gema Insani Press (ID), 2011 